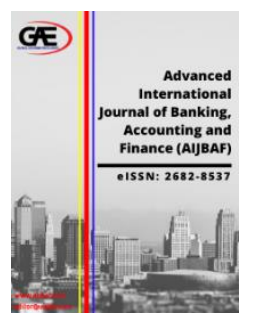

\author{
ADVANCED INTERNATIONAL JOURNAL OF \\ BANKING, ACCOUNTING AND FINANCE \\ (AIJBAF) \\ WWw.aijbaf.com
}

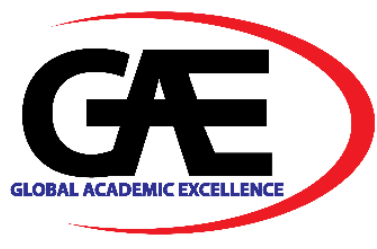

\title{
THE EFFECT OF CAPITAL STRUCTURE ON THE PERFORMANCE OF MALAYSIAN PLCs DURING A TRANSITION FROM SST TO GST
}

\author{
Asma Rina Abdul Rahman ${ }^{1}$, Noor Ayuernie Ibrahim ${ }^{2 *}$, Suria Abu Basar ${ }^{3}$ \\ 1 Faculty of Business \& Accountancy, Universiti Selangor, Malaysia \\ Email: asmarina@unisel.edu.my \\ 2 Faculty of Business \& Accountancy, Universiti Selangor, Malaysia \\ Email: noor_ayuernie@yahoo.com \\ 3 Faculty of Business \& Accountancy, Universiti Selangor, Malaysia \\ Email: suria@unisel.edu.my \\ Corresponding Author
}

\section{Article Info:}

\section{Article history:}

Received date: 15.10 .2019

Revised date: 23.10 .2019

Accepted date: 22.03.2021

Published date: 31.03 .2021

\section{To cite this document:}

Rahman, A. R. A., Ibrahim, N. A., \& Basar, S. A. (2021). The Effect of Capital Structure on the Performance of Malaysian PLCs during a Transition from SST to GST. Advanced International Journal of Banking, Accounting, and Finance, 3 (6), 69-81.

DOI: $10.35631 / A I J B A F .36007$.

This work is licensed under CC BY 4.0

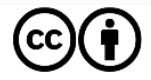

\section{Abstract:}

This study seeks to investigate the effect of capital structure on the corporate performance of Malaysian PLCs during a transition from SST to GST implementation. Especially focuses on the consumer products sector, 60 PLCs were chosen and financial data from 1st April 2014 until 1st April 2017 are observed. The result shows that GST implemented by the Malaysia Government leads to low corporate performance. Further, this study confirms that GST implementation has affected the capital structure and corporate performance of companies. This suggests that short-term debt tends to be less expensive and therefore increasing debt with a relatively low-interest rate will lead to an increase in profit levels. This result is consistent with the Static Trade-off Theory (Myers, 1984) whereby when debt is employed in capital structure, there will be a need for trade-off because firms are faced with the challenges of goods and services tax and bankruptcy cost.

Keywords:

GST Implementation, Capital Structure, Firm Performance, Consumer Products 


\section{Introduction}

Since the implementation of the Goods and Services Tax (GST) in April 2015, Malaysia has collected almost RM51 billions of taxes. GST is a broad-based consumption tax covering all sectors of the economy i.e. all goods and services made in Malaysia, including imports except specific goods and services which are categorised under zero-rated supply and exempt supply orders as determined by the Ministry of Finance and published in the Gazette. GST is a multistage tax, where a tax is added to the price of products or services at each stage of production and distribution (Mansor and Ilias 2013; Palil and Ibrahim 2012). A standard rate of 6 percent was applied to all goods and services in the hope that Malaysia would remain competitive in the international market (Ahmad 2015).

The main objective of GST implementation in Malaysia is to address the weaknesses in the existing taxation policy and also to serve as the key initiative under the Economic Transformation Programme (ETP) (Rashid et al. 2014). It also serves as a powerful means of revenue collection with the objective of reducing the fiscal deficit (Ling et al. 2016). The introduction of GST is also part of the government's tax reform programme which strives to enhance the capability, effectiveness and also transparency of tax administration and management. The difference between GST and the previous Sales and Service Tax (SST) is in terms of its scope of charge which is more comprehensive, inclusive of the manufacturing and distribution stages as well as providing a tax credit claim for GST paid on business inputs. When compared with the previous consumption tax system, the sales tax is imposed only at the manufacturing stage that is at the time when the goods are manufactured or when the goods are imported. On the other hand, service tax is imposed on specific services at the time when the services are provided to the consumer.

The basic fundamental of GST is its self-policing feature which allows businesses to claim their input tax credit by way of automatic deductions in their accounting system (Rashid et al. 2014). This eases the administrative procedures on the part of businesses and the government. Thus, the government's delivery system will be further enhanced. However, in reality to the implementation of GST, companies claimed that they are the most affected by the introduction of the GST due to lack of resources and funds to comply (Adam and Yusof 2018). Companies see significant impact on their revenue as they are the most in need to customise financial planning, tax filing, and invoice billing to comply with GST collection (Kim-Soon et al. 2018). With the implementation of GST, companies need to change their accounting system and business processes and must be ready to institute proper accounting record keeping, train their personnel and have proper software to ensure successful documentation and recording for the purpose of GST compliance. Thus, there is possibility that companies might face issues and problems pertaining to the compliance with GST legislations.

In analogous to Modigliani and Miller's (1963) propositions, Miller (1977) incorporated both corporate taxes and personal taxes into his model. Miller (1977) argued that the value of the firm depends on the relative level of each tax rate, compared with the other two. Miller (1977) indicated that relative level of each tax rate determines firm value, and that the gain from employing debt may be smaller than what was suggested in Modigliani and Miller (1963). In particular, this study assumes that GST implementation will affect the capital structure of the companies especially when companies facing limited budget, they tend to acquire more financial resources either debts or equity financing. With the current fluctuation in economic conditions, the burden faced by companies could lead to the assumption that companies should Copyright $\odot$ GLOBAL ACADEMIC EXCELLENCE (M) SDN BHD - All rights reserved 
Volume 3 Issue 6 (March 2021) PP. 69-81

DOI 10.35631/AIJBAF.36007

ensure that their capital structure is greatly weighted towards a higher level of debt. However there is a limit to the amount of debt a firm should take on (Özcan 2019). With the implementation of GST, questions arise of does capital structure positively or negatively impacts on corporate performance? Does higher leverage lead to better firm performance?

Therefore, the implementation of GST in Malaysia has motivated this study to examine the performance level in the period both before and after GST implementation among Malaysian Public Listed Companies (PLCs) especially in consumer products sector. Further, this study aims to investigate whether GST implementation has a moderation effect on the relationship between the capital structure and corporate performance of Consumer Products PLCs.

\section{Literature Review}

\section{The Impact of Capital Structure on the Corporate Performance}

Capital structure is one of the most perplexing puzzles in the financial literature that deals with solutions to optimal mix of debt and equity. The choice of different proportions of debt among mixed financing resources can impose major influences on the firm value, and thus on the wealth of the shareholders (Baker and Martin 2011). Since capital decision is one of the most important elements in corporate finance, it has attracted considerable concern of both academics and practitioners over the past few decades (Dao and Ta 2020). The seminal work of Modigliani and Miller (1958) initiated this body of work; other researchers later developed theories along the Modigliani and Miller. At the beginning of its theory development, capital structure was convinced to be irrelevant to the performance of companies, as suggested by Modigliani and Miller (1958, 1963). However, given the existence of an imperfect market's conditions and behaviors, the concept of optimal capital structure emerges with the proposal of trade-off theory that integrates the effect of corporate taxes, financial distress and agency problems.

The seminal work of Jensen and Meckling (1976) posits managerial behavior in the best interest of the shareholders which is to borrow at a level that will maximize shareholder value and firm performance. Since then, several researchers have examined the relationship between capital structure and firm performance. The findings of the studies, which target how capital structure affects a firm's performance, do not suggest uniform outcomes. The first group of studies reported a negative association between capital structure and firm performance. For instance, Özcan (2019) analysed how the capital structure of the publicly traded airport companies affects their profitability. Using an unbalanced panel data sample of 29 publicly traded airports from 20 countries over the 1989-2017 periods, Özcan (2019) found that higher total and long-term debt tend to decrease return on assets whereas they are positively associated with return on equity.

By using estimation of panel data fixed-effects regressions, Nenu et al. (2018) found that firm performance of companies listed on the Bucharest Stock Exchange appeared to be negatively related with short-term and long-term debt ratio, which is consistent with the Pecking Order Theory. Before that, Yazdanfar and Öhman's (2015) study used 15,897 Swedish SMEs from five different sectors from 2009 - 2012 to examine the effect of three different forms of debt ratios, namely as trade credit, short-term debt and long-term debt on firm's performance. Their results suggest a negative relationship between all types of debts and performance, suggesting an increased use of equity capital to finance Swedish SMEs. Dave et al. (2019) examined the Copyright $\odot$ GLOBAL ACADEMIC EXCELLENCE (M) SDN BHD - All rights reserved 
Volume 3 Issue 6 (March 2021) PP. 69-81

DOI 10.35631/AIJBAF.36007

impact of capital structure and performance of firms in the Indian Steel industry and observed a significant negative relationship between long-term and short-term debts as a ratio of total assets and profitability. Similarly, Gharaibeh and Bani Khaled (2020) examined the factors that played key roles in the performance of 46 Jordanian service sector companies between the years $2014-2018$. They found that debt as a portion of total assets and tangible assets have significantly negative relationships with performance. Recently, Nguyen and Nguyen (2020) revealed that the capital structure of 488 Vietnamese listed non-financial companies is negatively related to their performance between the years 2013 - 2018. In addition, they also found that the consumer goods industry had a higher relationship between capital structure and firm's performance (via ROE, ROA, EPS) than industrial product sectors.

The second group of research revealed the positive impact of capital structure on firm performance. For example, Ramli et al. (2019) compared the impact of capital structure determinants on firm financial performance in Malaysia and Indonesia over the period of 1990 - 2010. Their study revealed that Malaysian sample has a positive significant correlation between capital structure and firm financial performance. This indicates that Malaysian firms use external financing instead of internal financing to heighten performance. They are mostly insignificant for Indonesia. Margaritis and Psillaki (2017) used a sample of 12,240 companies in New Zealand. The study found that increasing debt led to an increase in firm performance, which showed a positive relationship between capital structure and firm performance. Nirajini and Priya (2013) and Al-Slehat (2020) also show that capital structure has a positive relationship with firm performance. Recently, Helmy et al. (2020) examined the impact of capital structure, internal governance mechanism, and firm-performance of 183 Bursa-listed Malaysian companies for the years 2007 - 2010. They found a positive impact of capital structure on firm performance.

The findings of the last group of studies suggested no association between capital structure and firm performance. Ebaid (2009) examined the influence of capital-structure choice on firm performance in Egypt. His study based on a sample of non-financial listed firms for the period 1997 to 2005 and used multiple regression analysis. Results suggested that firm performance has weak to no relationship with capital structure choice. Likewise, Ngatno et al. (2021) also found that long-term debt has a negative and insignificant effect on both return on assets and return on equity in Indonesia. Similarly, Hossain (2020) found that there is no significant relation exists between capital structure and firm's performance as measured by ROE and Tobin's Q in the 36 Bangladeshi firms listed in Dhaka Stock Exchange during the period 20072012.

\section{The Impact of Taxation on the Corporate Performance}

Previous researchers on capital structure have given different interpretations on the impact of taxation on corporate finance decisions. Mackie-Mason (1990), in his study on the impact of tax on corporate financing decisions, provides evidence that tax has a significant influence on choices between debt and equity. He concluded that changes in the marginal tax rate should affect financing decisions. A firm with a high tax shield is less likely to finance with debt, since tax shields lower the effective marginal tax rate on interest deductions. Graham (1996) concludes that, in general, taxes do affect corporate finance decisions, but the extent of this effect is insignificant. On the other hand, DeAngelo and Masulis (1980) showed that there are alternative tax shields such as depreciation, research and development costs and investment deductions that can substitute the role of debt. Titman and Wessels (1988) concluded that the Copyright (C) GLOBAL ACADEMIC EXCELLENCE (M) SDN BHD - All rights reserved 
Volume 3 Issue 6 (March 2021) PP. 69-81

substitution effect is difficult to measure as finding an accurate proxy for tax reduction that excludes the effect of economic depreciation and expenses is arduous.

Leland and Toft (1991) stated that the value of a firm is the value of its assets plus the value of tax benefits enjoyed as a result of debt minus the value of bankruptcy cost associated with debt. Modigliani (1980) pointed out that the value of a firm is the sum of its debt and equity and this depends only on the income stream generated by its assets. The value of the firm's equity is the discounted value of its shareholders earnings called net income. That is, the net income divided by the equity capitalization rate or expected rate of return on equity. The net income is obtained by subtracting interest on debt from net operating income. On the other hand, the value of debt is the discounted value of interest on debt.

For firms in the underdeveloped market, tax rates play a significant role in taking decisions about the optimal capital structure decisions (Karadeniz et al. 2009). Stulz (1988) argued that debt increases the likelihood for financial distress and debt also provides tax benefit. In practice, firms tend to use capital structure, preferred stock and common equity with which the firms plans to raise needed funds. Since capital structure policy involves a strategic trade-off between risk and expected return, the optimal capital structure policy must seek a prudent and informed balance between risk and return. The firm must consider its business risk, tax positions, financial flexibility and managerial conservatism or aggressiveness. While these factors are crucial in determining the target capital structure, operating conditions may cause the actual capital structure to differ from the optimal capital structure.

\section{Research Methodology}

Based on the views discussed in the literature reviews section, the proposed conceptual framework is developed based on the Pecking Order Theory (Myers and Majluf 1984) as well as Static Trade-off Theory (Myers 1984). Consistent with Pandey (2004), this study conjectures that the capital structure decision of a firm should be examined from the point of its impact on the value of the firm. Further, consistent with the Static Trade-off Theory (Myers, 1984), this study postulates that GST implementation in Malaysia has a moderation role on the relationship between the capital structure and corporate performance of Malaysian Consumer Products PLCs. Figure 1 is the research framework for this study.

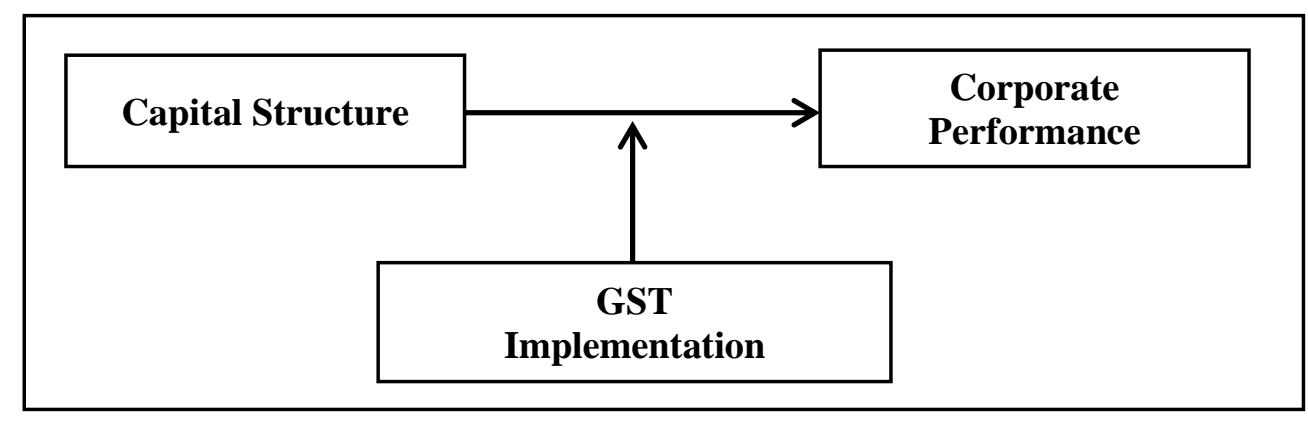

Figure 1: Conceptual Framework of the Study

\section{Data Collection Procedure}

This study focuses on the consumer products sector as it is believes that this industry is the most sector affected by the GST implementation. The selection process of the PLCs is based on the total market capitalization whereby 30 PLCs with the largest market capitalization and 
Volume 3 Issue 6 (March 2021) PP. 69-81

DOI 10.35631/AIJBAF.36007

30 PLCs with the smallest market capitalization, make it the total sample size was 60 PLCs. All the financial data was obtained from the annual report of the respective PLCs retrieved from the Bursa Malaysia website.

This study covers two different periods with regards to GST implementation. Depicted in Figure 2, the data will be collected in two different periods; (a) Period 1: Before GST implementation which cover the period from $1^{\text {st }}$ April 2014 to $31^{\text {st }}$ March 2015, and (b) Period 2: After GST implementation which cover the period from $1^{\text {st }}$ April 2016 to $31^{\text {st }}$ March 2017. After the implementation of GST on $1^{\text {st }}$ April 2015, there is a cooling period of one year. The decision for one year cooling period is taken based on the assumption that the impact of GST on the firms can be seen after one year of its implementation. In order to avoid any distortion of the effects from the recent and current listing, this study imposes two criteria on the sample so that it will not distort the results. The two criteria to be fulfilled by all companies included in the sample are that they must be listed in more than one year before GST implementation and none of them is expelled after one year of GST implementation period.

\section{Measurement of the Variables}

The effect of capital structure on corporate performance can be explained by using return on assets (ROA) and return on equity (ROE). The measurement of ROA and ROE are based on researcher Ahmad et al. (2012) whereby ROA is calculated as "net profit divided by total assets", while ROE is calculated as "earnings before interest and tax divided by equity". Further, this study measures the capital structure using short-term debt and long-term debt. Consistent with previous studies, the short-term debt is calculated as "short-term debt divided by total capital" (Ahmad et al. 2012; Jain et al. 2017). Next, following Jain et al. (2017), longterm debt is calculated as "long-term debt divided by total capital". While a dummy variable is created to measure the GST implementation. In this study, the period before GST implementation is measure as 0, while the period after GST implementation is denotes as 1.

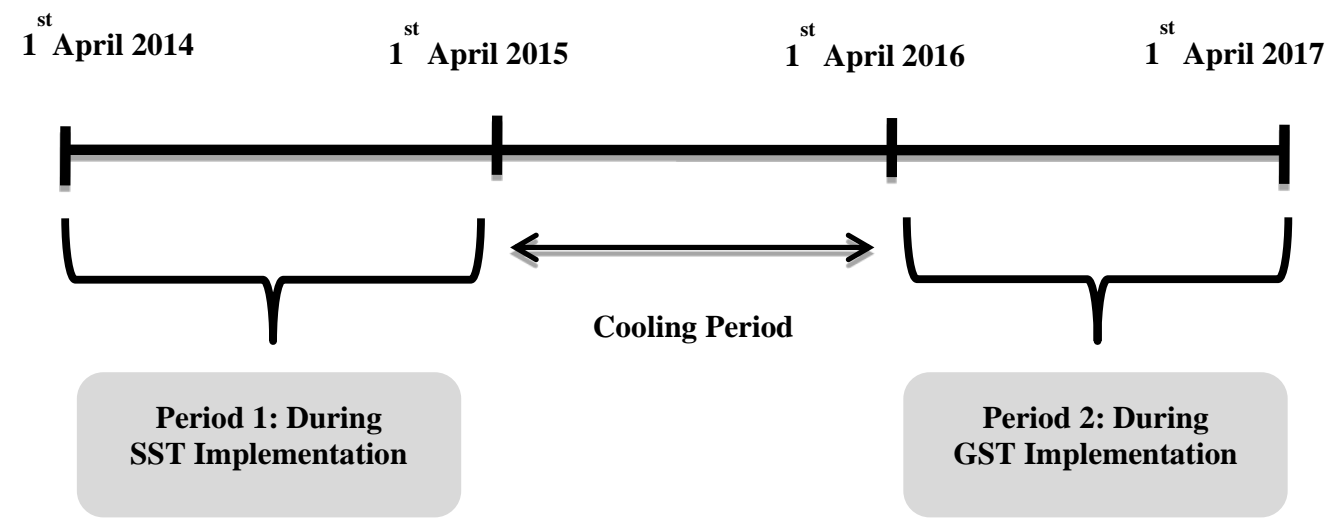

Figure 2: Research Timeline

This study also controls for other variables that affect firm performance. In this study, two control variables had been used that are firm size and sales growth. Following Ahmad et al. (2012), size is measured by the log of the total assets. While sales growth is measured by annual growth rate in sales which is consistent with Ahmad et al. (2012) and Ramli et al. (2019). 


\section{Results and Discussion}

\section{Corporate Performance of Malaysian Consumer Product PLCs}

Table 1 report that there is a statistically significant difference in the mean scores of performance level which measure using return on assets (ROA) and return on equity (ROE). This result indicates that there is a difference in the performance level of Malaysian Consumer Products PLCs during SST period and after GST implementation. For instance, the corporate performance in term of return on assets (ROA) of the sample firms is lower in the period after GST implementation. Contrary, the performance of return on equity (ROE) is lower in the period of SST implementation and increased after the GST implementation.

Table 1: Corporate Performance Before and After GST Implementation

\begin{tabular}{lccccc} 
Variables & n & $\begin{array}{c}\text { Before } \\
\text { GST: Mean }\end{array}$ & $\begin{array}{c}\text { After GST: } \\
\text { Mean }\end{array}$ & \multicolumn{2}{c}{ Independent Sample $\boldsymbol{t}$-test } \\
\cline { 6 - 7 } & & 7.611 & 3.590 & $\mathbf{- 4 . 8 2 3}$ & $\mathbf{. 0 0 4}$ \\
Return on Assets & 60 & & & & \\
Return on Equity & 60 & 7.911 & 22.369 & $\mathbf{3 . 5 4 5}$ & $\mathbf{. 0 1 2}^{* *}$ \\
\hline
\end{tabular}

Note: Result is significantly different from zero at the ${ }^{* * *} 1$ percent level and ${ }^{* *} 5$ percent level, respectively, using two-tailed tests.

In order have closer look on the difference in the performance level of Malaysian Consumer Products PLCs during before and after GST implementation for different groups of market capitalization, the analyses are conducted separately for the PLCs in largest as well as smallest market capitalization. Panel A of Table 2 show that there is a significant difference in the mean of ROA ( $t$-statistic $=-4.481$ ) for PLCs in largest market capitalization during before and after GST implementation and it is statistically significant at $1 \%$ level. This finding suggests that the performance of companies is reduced after the implementation of GST. However, there is no evidence that 30 PLCs in largest market capitalization are difference in performance of return on Equity (ROE).

Table 2: Corporate Performance Before and After GST Implementation of 30 Largest and 30 Smallest PLCs based on Market Capitalization

\begin{tabular}{|c|c|c|c|c|c|}
\hline \multirow{2}{*}{ Variables } & \multirow[b]{2}{*}{$\mathbf{n}$} & \multirow{2}{*}{$\begin{array}{l}\text { Before } \\
\text { GST: } \\
\text { Mean }\end{array}$} & \multirow{2}{*}{$\begin{array}{c}\text { After GST: } \\
\text { Mean }\end{array}$} & \multicolumn{2}{|c|}{ Independent Sample $t$-test } \\
\hline & & & & $t$-statistic & $p$ value \\
\hline
\end{tabular}

Panel A: 30 Largest PLCs based on Market Capitalization

\begin{tabular}{llllll} 
Return on Assets & 30 & 17.25 & 14.27 & $\mathbf{- 4 . 4 8 1}$ & $\mathbf{. 0 0 6}^{\text {**** }}$ \\
Return on Equity & 30 & 32.82 & 34.04 & 0.106 & $.916^{\text {NS }}$ \\
\hline
\end{tabular}

Panel B: 30 Smallest PLCs based on Market Capitalization

\begin{tabular}{cccccc} 
Return on Assets & 30 & -2.029 & -7.091 & $\mathbf{- 3 . 7 5 8}$ & $\mathbf{. 0 0 4}^{\text {**** }}$ \\
Return on Equity & 30 & -16.997 & 10.695 & $\mathbf{2 . 1 2 5}$ & $\mathbf{. 0 3 8}^{* *}$ \\
\hline $\begin{array}{l}\text { Note: } \text { Result is significantly different from zero at the } \\
\text { using two-tailed tests. }\end{array}$
\end{tabular}


Volume 3 Issue 6 (March 2021) PP. 69-81 DOI 10.35631/AIJBAF.36007

Further, comparison in corporate performance is also conducted for 30 smallest market capitalization PLCs. Panel B in Table 2 reveals that there is a significant difference in the performance level before and after GST implementation for all two measurements of performance. Similar to the overall result in Table 1, the return on assets (ROA) of 30 PLCs in the smallest market capitalization is lowered in the period after GST implementation, while the return on equity (ROE) is increased after the GST implementation.

\section{Capital Structure of Malaysian Consumer Product PLCs}

Table 3 reports that there is a statistically significant difference in the mean scores of capital structure for short-term debt, but no evidence of difference in the mean scores of long-term debts during and after GST implementation. This result indicates that short-term debt of Malaysian consumer products PLCs are significantly increased in the period after GST implementation. Further, the result indicates that short-term debt dominates debt choices of Malaysian consumer product PLCs. This result is contradicted with Australian context whereby Ahmed and Afza (2019) found that long-term debt dominates debt choices of service sector companies.

Table 3: Capital Structure Before and After GST Implementation

\begin{tabular}{|c|c|c|c|c|c|}
\hline \multirow{2}{*}{ Variables } & \multirow{2}{*}{$\mathbf{n}$} & \multirow{2}{*}{$\begin{array}{c}\text { Before } \\
\text { GST: Mean }\end{array}$} & \multirow{2}{*}{$\begin{array}{c}\text { After GST: } \\
\text { Mean }\end{array}$} & \multicolumn{2}{|c|}{ Independent Sample $t$-test } \\
\hline & & & & $t$-statistic & $p$ value \\
\hline Short-term Debt & 60 & 0.6812 & 0.8457 & 4.932 & $.003^{* * *}$ \\
\hline Long-term Debt & 60 & 0.2108 & 0.0872 & 1.387 & $.168^{\mathrm{NS}}$ \\
\hline
\end{tabular}

Independent sample t-test has been also conducted to identify the difference in the capital structure of consumer products PLCs during before and after GST implementation for different groups of market capitalization. Panel A and Panel B of Table 4 show that there is a significant difference in the mean of short term debt for PLCs in largest market capitalization ( $t$-statistic $=3.197)$ and smallest market capitalization $(t$-statistic $=-3.245)$ during before and after GST implementation and it is statistically significant at $1 \%$ level. This finding suggests that the size of short-term debt is increased for 30 PLCs in largest market capitalization, but reduced for 30 PLCs in smallest market capitalization after the implementation of GST. However, there is no evidence that both groups of PLCs are different in their long-term debt before and after GST implementation.

Table 4: Capital Structure Before and After GST Implementation of 30 Largest and 30 Smallest PLCs based on Market Capitalization

\begin{tabular}{|c|c|c|c|c|c|}
\hline \multirow[b]{2}{*}{ Variables } & \multirow[b]{2}{*}{$\mathbf{n}$} & \multirow{2}{*}{$\begin{array}{l}\text { Before } \\
\text { GST: } \\
\text { Mean }\end{array}$} & \multirow{2}{*}{$\begin{array}{c}\text { After GST: } \\
\text { Mean }\end{array}$} & \multicolumn{2}{|c|}{ Independent Sample $t$-tes } \\
\hline & & & & $t$-statistic & $p$ value \\
\hline
\end{tabular}

Panel A: 30 Largest PLCs based on Market Capitalization

$\begin{array}{llllll}\text { Short-term Debt } & 30 & 0.572 & 0.604 & \mathbf{3 . 1 9 7} & \mathbf{. 0 0 8}^{* * * *} \\ \text { Long-term Debt } & 30 & 0.162 & 0.146 & -0.778 & .778^{\text {NS }}\end{array}$




\section{Panel B: 30 Smallest PLCs based on Market Capitalization}

\begin{tabular}{cccccc} 
Short-term Debt & 30 & 0.793 & 0.487 & $\mathbf{- 3 . 2 4 5}$ & $\mathbf{. 0 0 2}^{\text {**** }}$ \\
Long-term Debt & 30 & 0.260 & 0.028 & -1.364 & $.179^{\mathrm{NS}}$ \\
\hline $\begin{array}{l}\text { Note: } \text { Result is significantly different from zero at the } \\
\text { using two-tailed tests. }\end{array}$ & &
\end{tabular}

The Effect of Capital Structure on the Corporate Performance Due to GST Implementation The main objective of this study is to investigate whether GST implementation has a moderation role on the relationship between the capital structure and corporate performance of consumer products PLCs. The hierarchical regression analysis is conducted to find out the magnitude impact of the GST implementation on the relationship between capital structure and corporate performance. A series of regression analyses were executed for two different models according to the measures of dependent variable, i.e. corporate performance, whereby Model 1 is using return on assets (ROA) and Model 2 is based on return on equity (ROE).

Table 5 reveals that the $F$-statistics for the Models 1 and Model 2 is 4.826 and 5.896, respectively, while the $p$-value is significant $(p$-value $=.000)$ for both models, which indicate significant at $1 \%$ level. In addition, the $\mathrm{R}^{2}$ values for both models are $25.8 \%$ and $29.8 \%$, respectively. These show that the estimated models explain respectively $25.8 \%$ and $29.8 \%$ of changes in dependent variable.

Table 5: Hierarchical Regression Results

\begin{tabular}{|c|c|c|c|c|c|c|}
\hline \multirow{2}{*}{ Variables } & \multicolumn{3}{|c|}{ Model 1: ROA } & \multicolumn{3}{|c|}{ Model 2: ROE } \\
\hline & Beta & $t$-stat & $p$ value & Beta & $t$-stat & $p$ value \\
\hline Intercept & & -1.613 & .110 & & -1.574 & .118 \\
\hline Short-term Debt (STD) & 0.310 & 2.075 & $.009^{* * * *}$ & -0.200 & -1.857 & $.066^{*}$ \\
\hline Long-term Debt (LTD) & 0.025 & 0.222 & .824 & -0.400 & -3.864 & $.000^{* * * *}$ \\
\hline GST & -0.215 & -2.057 & $.042^{* *}$ & -0.029 & -3.282 & $.007^{* * *}$ \\
\hline STD*GST & 0.275 & 2.043 & $.043^{* *}$ & 0.238 & 3.910 & $.005^{* * *}$ \\
\hline LTD*GST & -0.007 & -0.071 & .944 & -0.106 & -0.988 & .325 \\
\hline Firm Size & 0.166 & 1.868 & $.064^{*}$ & 0.174 & 2.081 & $.040^{* *}$ \\
\hline Sales Growth & 0.298 & 3.279 & $.001^{* * * *}$ & 0.091 & 1.050 & .296 \\
\hline $\mathrm{R}^{2}$ value (\%) & & $25.8 \%$ & & & $29.8 \%$ & \\
\hline F value & & $4.826^{* * *}$ & & & $5.896^{* * * *}$ & \\
\hline No. of Observations & & 120 & & & 120 & \\
\hline
\end{tabular}

For the effect of GST implementation on the corporate performance measures, a dummy variable GST has been added to the models. The results in the Table 4 shows that the GST implementation has a significant negative impact on the return on assets (ROA) and return on equity (ROE). This indicates that the GST implemented by the Malaysia Government lead to Copyright (C) GLOBAL ACADEMIC EXCELLENCE (M) SDN BHD - All rights reserved 
Volume 3 Issue 6 (March 2021) PP. 69-81

DOI 10.35631/AIJBAF.36007

the low return on assets (ROA) and return on equity (ROE) in the consumer products sector during the period investigated in this study. Finally, this study conjectures that GST implementation has a mediation role on the relationship between capital structure and corporate performance. After controlling for firm size and growth, the result in Table 4 reveals that the GST implementation has a moderation role on the relationship between short-term debt (STD) and corporate performance (return on assets (ROA)) and shareholders' return (return on equity (ROE)) of Malaysian Consumer Products PLCs and it is statistically significant at 5\% and 1\% level, respectively for Model 1 and Model 2.

\section{Conclusion}

Capital structure decision making is vital for the success of a company. Equity and debts are the two main sources of finance for a company. The choice of right proportion of debt and equity in capital structure will help in increasing the company's profitability. Debt on one hand allows companies to do things that they would not be able to do otherwise, but on the other hand it also increases overall risk of the company. There is slight difference of opinion about the role of debt in profitability. The literature reveals different results under different circumstances.

Overall, this study concludes that the performance level of Malaysian Consumer Products PLCs during the SST implementation period \& after GST implementation is different. It is observed that the corporate performance and shareholders' equity are lower in the period after GST implementation. Perhaps, the transition from SST to GST implementation may have some impact to the performance of these PLCs. Besides, the result reveals that PLCs in 30 lowest market capitalization has negative return on assets (ROA) for the period after GST implementation. This indicates that these PLCs are badly affected due to GST as compared to its counterpart.

Two general regression models are utilized as the dependent variable, i.e. return on assets (ROA) and return on equity (ROE) to assess the effect of capital structure on corporate performance. A series of standard multiple regression analysis were executed for each model, where either one of the capital structure proxies is included in each analysis. In summary, all capital structure indicators has a positive effect on the corporate performance (ROA) after the GST implementation. This finding is consistent with Pecking Order Theory (Myers \& Majluf, 1984), which states that there is a positive relationship between the debt levels and the profitability of a company. In addition, studied by Grossman and Hart (1986) who argued that higher levels of debt in the firm's capital structure will be directly associated with higher performance levels.

Contrary, long-term debt (LTD) and short-term debt (STD) has a negative effect on shareholders' return (ROE) regardless of GST implementation. Thus, the higher the debt, the lower the shareholders' profitability. It concurs with Pecking order theory. Debt appears to be more costly due to certain reasons, therefore increasing the proportion of debt in capital structure will results in low profitability for shareholders. The results of this study concur with Habib et al. (2016) and Kebewar (2013). This result implies that that capital structure has an immediate or long term effect on returns to shareholders. Even though returns to the firm as whole increase with the increase in long-term debt (LTD) level, this does not contribute to higher return to equity holders. 
Volume 3 Issue 6 (March 2021) PP. 69-81 DOI 10.35631/AIJBAF.36007

Finally, the findings of this study reveal that GST implemented by the Malaysia Government lead to the low corporate performance and shareholders' return in the consumer products sector during the period investigated in this study. The hierarchical regression results confirm that GST implementation has a moderation role on the relationship between the capital structure (short-term debt (STD)) and corporate performance of Consumer Products PLCs. The positive sign of beta coefficient indicates that once GST has been implemented in Malaysia, PLCs in consumer products sectors have to increase their short-term debt level in order to enhance their corporate performance. This suggest that short-term debt tends to be less expensive and therefore increasing short-term debt with a relatively low interest rate will lead to an increase in profit levels. This result is consistent with the Static Trade-off Theory (Myers, 1984) whereby when debt is employed in capital structure, there will be a need for trade-off because firms are faced with the challenges of tax and bankruptcy cost.

\section{Limitations \& Recommendation of Future Research}

Some limitations of this study should be acknowledged and directions for future studies should also be suggested. First, this study is focused on companies in consumer products sector listed on the Bursa Malaysia and therefore the findings of this study does not represent unlisted companies or companies listed on other stock exchanges. Hence, to get a better picture for future studies, it can include more sectors such as construction, plantation, infrastructure and others in the research. Besides, it was restricted to the financial data of PLCs for the one year before and after the GST implementation on the $1^{\text {st }}$ April 2015. It therefore does not represent time periods beyond this. It thus suggested that one can extend the analyses time to cover the longer time period. This will give a full understanding of how debt works over the business cycle and affects the overall performance of the company. Although this study focuses on the variables that were repeatedly used by other researchers to explain firm operating performance, however this study found low explanatory power of these variables. Thus, suggestion for further researchers should seek other firm characteristics variables such as Tobin's Q and gross profit margin that might provide better explanation of firm operating performance before we would suggest that fundamental analysis of a firm is of little value to investors.

\section{References}

Adam, M. N. H., \& Yusof, N. A. M. (2018). A comparative study on the burden of tax compliance costs amongst GST registered companies in Malaysia and abroad. Journal of Science, Technology and Innovation Policy, 3(2), 21-34.

Ahmad, N. (2015). GST Untuk Bisnes \& Peniaga: 40 Soalan Penting Untuk Memahami GST Dan Pelaksanaannya Di Malaysia. (1st ed.). Selangor: TrueWealth Sdn Bhd.

Ahmad, Z., Mohd Hasan Abdullah, N., \& Roslan, S. (2012). Capital structure effect on firms performance: Focusing on consumers and industrials sectors on Malaysian firms. International Review of Business Research, 8(5), 137-155.

Ahmed, N., \& Afza, T. (2019). Capital structure, competitive intensity and firm performance: Evidence from Pakistan. Journal of Advances in Management Research. 13(1), 214230.

Al-Slehat, Z. A. F. (2020). Impact of financial leverage, size and assets structure on firm value: Evidence from industrial sector, Jordan. International Business Research, 13(1), 109120.

Baker, H. \& Martin, G. (2011), Capital Structure and Corporate Financing Decisions: Theory, Evidence, and Practice. John Wiley and Sons. 
Volume 3 Issue 6 (March 2021) PP. 69-81 DOI 10.35631/AIJBAF.36007

Dao, B. T. \& Ta, T. D. (2020). A meta-analysis: Capital structure and firm performance. Journal of Economics and Development, 22(1), 111-129.

Dave, A., Ashwin, P., Ashish, J., \& Tejas, D. (2019). A study of capital structure and profitability of Indian steel sector companies. International Journal of Advanced Science and Technology, 28(1), 866-873.

DeAngelo, H., \& Masulis, R. (1980). Optimal capital structure under corporate and personal taxation. Journal of Financial Economics, 8, 3-29.

Ebaid, I. E. S. (2009). The impact of capital-structure choice on firm performance: Empirical evidence from Egypt. Journal of Risk Finance, 10(5), 477-487.

Gharaibeh, O. K. \& Marie, H. B. K. (2020). Determinants of profitability in Jordanian services companies. Investment Management and Financial Innovations, 17(1), 277-290.

Graham, J. R. (1996). Proxies for the marginal tax rate. Journal of Financial Economics, 42, 187-221.

Grossman, S., \& Hart, O. (1986). The costs and benefit of ownership: A theory of vertical and lateral integration. Journal of Political Economy, 94, 691-719.

Habib, H., Khan, F., \& Wazir, M. (2016). Impact of debt on profitability of firms: Evidence from non-financial sector of pakistan. City University Research Journal, 6(1), 70-80.

Helmy, M. H. Z., Goh, C. F., Tan, O. K., Onn, C. H., Tan, S. T., Lim, K. Y., \& Wong, C. H. (2020). Capital structure, internal governance mechanisms and firm performance. International Journal of Psychosocial Rehabilitation, 24(1), 7313-7321.

Hossain, T. (2020). Determinants of profitability: A study on manufacturing companies listed on the Dhaka Stock Exchange. Asian Economic and Financial Review, 10(12), 14961508 .

Jain, S., Bhargava, A., \& Bhargava, A. (2017). Impact of capital structure on profitability of Indian manufacturing firms. Asian Journal of Research in Banking and Finance, 7(7), 299-306.

Jensen, M. C., \& Meckling, W. H. (1976). Theory of the firm: Managerial behavior, agency costs and ownership structure. Journal of Financial Economics, 3(4), 305-360.

Karadeniz, E., Kandir, S. Y., Balcilar, M., \& Onal, Y. B. (2009). Determinants of capital structure: Evidence from Turkish lodging companies. International Journal of Contemporary Hospitality Management, 21(5), 594-609.

Kim-Soon, N., Ahmad, A. R., Chun, H. K., \& Hasaballah, A. H. A. (2018). A preliminary assessment of transition of SST to GST tax regime of SMEs. Advanced Science Letters, 24(5), 3022-3025.

Leland, H. E., \& Toft, K. (1991). Optimal capital structure, endogenous bankruptcy, and the term structure of credit spreads. Journal of Finance, 51, 987-1019.

Ling, S. C., Osman, A., Muhammad, S., Yeng, S. K., \& Jin, L. Y. (2016). Goods and Services Tax (GST) compliance among Malaysian consumers: The influence of price, government subsidies and income inequality. Procedia Economics and Finance, 35, 198-205.

Mackie-Mason, J. K. (1990). Do taxes affect corporate finance decisions? The Journal of Finance, 45, 1471-1493.

Mansor, N. H. A., \& Ilias, A. (2013). Goods and Services Tax (GST): A new tax reform in Malaysia. International Journal of Economics Business and Management Studies, 2(1), 12-19.

Margaritis, D., \& Psillaki, M. (2017). Capital structure and firm efficiency. Journal of Business Finance \& Accounting, 34(9-10), 1447-1469.

Miller, M. H. (1977). Debt and taxes. Journal of Financial Economics, 32(2), 261-275.

Copyright (C) GLOBAL ACADEMIC EXCELLENCE (M) SDN BHD - All rights reserved 
Volume 3 Issue 6 (March 2021) PP. 69-81 DOI 10.35631/AIJBAF.36007

Modigliani, F. (1980). Introduction. In Abel (Ed.), The Collected Papers of Franco Modigliani (Vol. 3, pp. xi-xix). Cambridge, Massachusetts: MIT Press.

Modigliani, F., \& Miller, M. (1958). The cost of capital, corporation finance and the theory of investment. American Economic Review, 48, 261-297.

Modigliani, F., \& Miller, M. (1963). Corporate income taxes and the cost of capital: A correction. American Economic Review, 53, 433-443.

Myers, S. C. (1984). The capital structure puzzle. The Journal of Finance, 39(3), 575-592.

Myers, S. C., \& Majluf, N. S. (1984). Corporate financing and investment decisions when firms have information that investors do not have. Journal of Financial Economics, 13(2), 92-118.

Nenu, E. A., Vintilă, G., \& Gherghina, Ş. C. (2018). The impact of capital structure on risk and firm performance: Empirical evidence for the Bucharest Stock Exchange listed companies. International Journal of Financial Studies, 6(2), 41-56.

Ngatno, Apriatni, E. P., \& Youlianto, A. (2021). Moderating effects of corporate governance mechanism on the relation between capital structure and firm performance. Cogent Business \& Management, 8(1), 18-26.

Nguyen, T., \& Nguyen, H. (2020). Capital structure and firm performance of non-financial listed companies: Cross-sector empirical evidences from Vietnam. Accounting, 6(2), 137-150.

Nirajini, A., \& Priya, K. (2013). Impact of capital structure on financial performance of the listed trading companies in Sri Lanka. International Journal of Scientific Research Publications, 3(5), 1-9.

Özcan, İ. Ç. (2019). Capital structure and firm performance. European Journal of Transport and Infrastructure Research, 19(3), 177-195.

Palil, M. R., \& Ibrahim, M. A. (2012). The impacts of Goods and Services Tax (GST) on middle income earners in Malaysia. World Review of Business Research, 1(3), 192-206.

Pandey, I. M. (2004). Financial Management. (9th Ed.). Ahmedabad: Vikas Publishing House.

Ramli, N. A., Latan, H., \& Solovida, G. T. (2019). Determinants of capital structure and firm financial performance - A PLS-SEM approach: Evidence from Malaysia and Indonesia. The Quarterly Review of Economics and Finance, 71, 148-160.

Rashid, S. N., Yusoff, P. D., \& Nor, N. H. (2014). Study on the Possible Impact of GST Towards Malaysia Using Selected Economic Indicators: Case of Singapore, Thailand and Indonesia as Model Countries. 5th International Conference on Business and Economic Research (5th ICBER) Proceedings. Sarawak, Malaysia.

Stulz, R. (1988). Managerial control of voting rights: Financing policies and the market for corporate control. Journal of Financial Economics, 20, 25-54.

Titman, S., \& Wessels, R. (1988). The determinants of capital structure choice. The Journal of Finance, 43(1), 1-19.

Yazdanfar, Darush. (2012). The impact of financing pattern on firm growth: Evidence from Swedish micro firms. International Business Research, 5(1), 16-29. 